\title{
Effect of Bid Ask Spread, Profitability, and Free Cash Flow on Earning Management
}

\author{
Nurainun Bangun \\ Faculty of Economic, Tarumanagara University, Jakarta \\ Email: nurnainunb@fe.untar.ac.id
}

\begin{abstract}
The purpose of this study was to determine the effect of bid ask spread, profitability, and free cash flow on earnings management. The population in this study are manufacturing companies listed on the Indonesia Stock Exchange in 2016-2018. The sampling method used was purposive sampling with predetermined criteria. Earning management is determined by the accruals method. The results of this study stated that the bid ask spread did not have a significant effect on earnings management, while profitability and free cash flow had a significant effect on earnings management.
\end{abstract}

Keywords: bid ask spread, profitability, free cash flow, earning management.

\section{INTRODUCTION}

Financial statements are reports that describe the current state of the company in a certain period (Kasmir, 2014). Financial statements are used as a basis not only by investors but also creditors and management in decision making. When the financial statements do not describe the actual state of the company, the decisions taken can be mistaken and detrimental to its users. Management should ensure that the financial statements display the company's condition effectively and efficiently so that it is attractive. This reason drives earnings management to attract external parties to invest in the company.

Some cases of earnings management that occurred in Indonesia include PT Kimia Farama's case in 2001 where there was an overstated profit of Rp 32.7 billion because the company reported a profit that was greater than it actually was (BAPEPAM). Another case that was detected doing earnings management was the case of PT Indofarma which was found to be overstated in the inventory account of Rp 28.82 billion and an understated cost of goods sold account that caused overstated in the net profit account (BAPEPAM). The most recent case detected in managing earnings is the case of Garuda Indonesia where Garuda reported a profit of US \$ 809.84 thousand, whereas it had previously suffered a loss of US \$ 216.58 million.

Earnings management is an activity where management interferes in the preparation of financial statements for external parties by increasing or decreasing company profits in accordance with the current state of the company (Putri and Sujana, 2018). Differences in interests between internal and external parties can also encourage earnings management based on agency theory. Agency theory states that management is given authority by the board of directors or shareholders to run and manage the company.

One of the factors that can influence earnings management is information asymmetry which is usually measured by bid ask spread. Bid ask spread is the distance between the lowest price offered and the highest price requested, this distance can cause information 
asymmetry. Information asymmetry occurs when internal parties know more information than external parties, as well as future company prospects that are known by management compared to shareholders (Hanifah, 2015). Research conducted by (Wiyadi et al., 2015) and (Putu et al., 2015) found that bid ask spread had a significant effect on earnings management while research conducted by (Hanifah, 2015) stated that bid ask spread had no significant effect on earnings management.

Earning management can also be influenced by the profitability of a company. Profitability is the company's ability to generate profits in a certain period of time. Profitability is considered to describe what company performance is running effectively and efficiently. When a company has a high level of profitability, the company is considered to have good performance which will be reflected through the published financial statements. The financial statements will be used in decision making by investors to make investments. When profitability is low, management will be encouraged to do earnings management because if the profitability of a company is low or experiences losses, this is in the eyes of investors is a sign that it does not make investments in the company (Mulyana et al., 2018). Research conducted by (Agustia and Suryani, 2018), (Firtri et al., 2018) shows that profitability has a significant effect on earnings management while research conducted by (Alexander and Hengky, 2017) states that profitability does not significantly influence earnings management.

Free cash flow can also affect the practice of earnings management. Free cash flow can be defined as the company's cash holdings when the company has finished financing all investment activities carried out and working capital used for operational activities in developing its business for the company's future (Yogi and Damayanthi, 2016). Free cash flow illustrates how much the company's ability to survive in a bad situation so that the greater the free cash flow the company has, the greater its ability to survive. When the free cash flow of a company is small, its ability to financing the investment and capital for its operational activities will not be fulfilled so that new sources of funding will be needed to meet its needs (Ramadhani et al., 2017). This is what drives management to make earnings management when free cash flow is high, investors will be more interested in investing their capital in the company. Research conducted by (Nekhili et al., 2016) found that free cash flow has a significant effect on earnings management while research conducted by (Ramadhani et al., 2017) states that free cash flow has no significant effect on earnings management.

\section{THEORITICAL REVIEW}

Agency Theory. Agency theory is a theory that provides an explanation of the relationship between shareholders or investors with management, where investors and shareholders will give authority to the management to carry out their obligations in managing the company. When both have the same goal, management will carry out the tasks assigned by the shareholders well, but conversely if there are differences in interests between the two parties, there will be conflict and negligence in carrying out the obligations for the given task. Investors assume that the management as an agent has an obligation as a guard to ensure that the investment has been carried out in a balanced manner for both parties and not only benefitting one side and the management is not even taking advantage of the opportunities that exist in the investment process (Saftiana et al., 2017). 
Signaling Theory. This signal theory explains that various actions or decisions taken by the company can be used as a signal about the state of the company, so that investors can consider these various signals before making a decision to invest in the company. Signal theory is the basis for looking at information asymmetry, when companies have more information than investors, this can be a signal by investors that there may be manipulation of their financial statements. Management will provide a signal so that information asymmetry within the company can be reduced by using the accruals method (Putri and Sujana, 2018). Information asymmetry is usually seen from the company's bid ask spread. Bid ask spread shows the distance between the price offered and the price requested by investors due to differences in information held by both parties. It can be concluded that management will provide true information about the state of the company so as to increase the trust of shareholders and provide evidence that management has high credibility.

Positive Accounting Theory. Positive accounting theory is a theory that explains the relationship between accounting policies used by management in recording various transactions and how the company responds to the applied policies. There are three hypotheses in positive accounting theory that encourage management to conduct earnings management, the first is the bonus plan hypothesis where when the company gets high profits, employees will get a large bonus so this encourages earnings management. The second hypothesis is to equity hypothesis or debt covenant hypothesis where when the company has a high debt ratio, the company will find it difficult to get a loan so that the management will do earnings management to reduce the level of loans with the accounting method. Third is the political cost hypothesis where when a company has a large profit then it must pay a large tax, then management will try to reduce the company's profit to avoid the government policy (Ghanbari et al., 2016).

The effect of bid ask spread, profitability, and free cash flow on earnings management. (Wiyadi et al., 2018) in his study found that information asymmetry measured by bid ask spread affects earnings management, in other words when there is a large distance between bid and ask prices that indicate there is information asymmetry, the greater the possibility of earnings management. Bid ask spread is basically the difference between the highest price requested or what the buyer wants to pay and the lowest price offered or acceptable to the seller (Dewi and Kartika, 2016). There are two kinds of information asymmetry, the first is adverse selection where internal parties know more about the company's prospects than external parties that are not delivered. Second is moral hazard where shareholders do not know that management has carried out such manipulation activities (Ali and Abdelfettah, 2016). This spread is caused by the management having more information than external parties such as investors, creditors, and others. When internal parties have more information then management can take advantage of this situation for their own interests as he might be able to provide information to his family to invest in the company because the company is in good condition so that it can provide great benefits for him otherwise he can tell to withdraw investment because the company is getting worse and may be bankrupt so that it will not suffer losses. Management generally knows the company's prospects going forward so that because of this opportunity, he will conduct earnings management to meet his own interests. 
Profitability is the ratio used in measuring the ability of a company to generate profits in a certain time period (Gunawan et al., 2015). Profitability can be used as an indicator in seeing the company's ability to manage its assets (Wiyadi et al., 2015). The level of profitability that is owned by each company is different so that the level of profitability is often used as a basis for investing in a company. This is what drives management to conduct earnings management. When the level of profitability of a company is high, investors will be more interested in investing because it is likely to get greater profits, whereas when the profitability of a company is low, investors will switch to investing in companies that have a higher level of profitability. Management will be compelled to do earnings management because of reasons to get additional funds from more external parties.

Free cash flow is the company's cash that will be distributed to shareholders as dividends or to credit parties after the company has completed its various investment activities and capital (Nekhili et al., 2016). In a study conducted by (Cardoso et al., 2014), (Bukit and Nasution, 2015), and (Chintya and Indriani, 2015) stated that there is a relationship between free cash flow and earnings management. This relationship is based on agency theory where there are differences in interests between management and shareholders. The shareholders clearly want dividend rewards, in this case if the free cash flow of a company is getting bigger, the greater the dividend will be received, on the other hand the management wants free cash flow to be used for investment activities so the company will be able to show good prospects. When the company has good future prospects, the management will get credit because the company's prospects describe the performance and how to work well so that management will get a reward or bonus. Management will increase its own profits and this is what drives earnings management. Free cash flow of a company can also be a signal for investors to see the state of a company before investing.

The framework of thought from the results of the discussion above can be described as follows

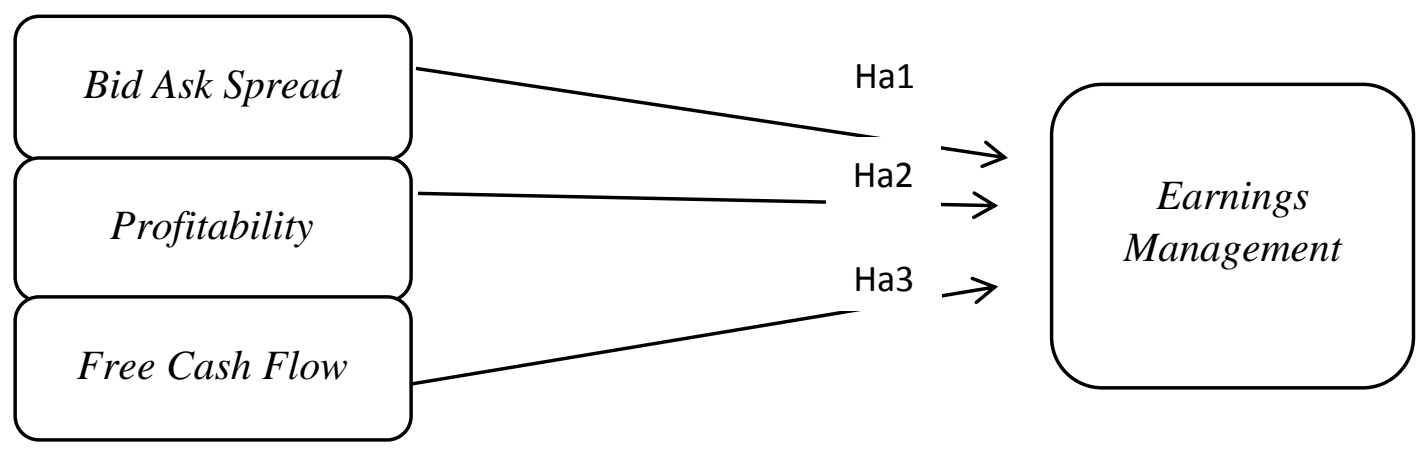

The hypothesis is formulated as follows:

Ha1: Bid ask spread has a significant positive effect on earnings management.

Ha2: Profitability has a significant positive effect on earnings management.

Ha3: Free cash flow has a significant positive effect on earnings management.

\section{METHODOLOGY}

This research uses quantitative type by using a descriptive approach. This research was conducted at manufacturing companies listed on the Indonesia Stock Exchange (IDX) in 
2016-2018. Data in the form of financial reports obtained were obtained from the official website of the IDX, www.idx.co.id. The method of taking samples from the population is purposive sampling where in this method the researcher has determined the criteria rather than the sample first (Sugiyono, 2017). The authors used are as follows: (1) Manufacturing companies listed on the IDX successively in 2015-2018. (2) The company publishes financial statements in a row in 2015-2018. (3) The company presents financial statements by using a rupiah currency in 2015-2018. (4) The Company made a profit in a row in 20152018.

Operational variables consist of two variables, the dependent variable and the independent variable. The independent variables used are bid ask spread, profitability, and free cash flow while the dependent variable is earnings management.

Dependent Variable. Discretionary accruals are used as proxies in calculating earnings management and the modified Jones Model is used because it is considered to have the ability to find earnings management better than other models. (Saftiana et al., 2017).

\section{First Step}

Calculates the total value of accruals

$$
\text { TACCit }=\text { NIit }- \text { OCFit }
$$

Information:

TACCit : total company accrual $\mathrm{i}$ in the $\mathrm{t}$-period

Nlit $\quad:$ net profit of company $i$ in the t-period

OCFit : cash operating activities of the company $i$ in the t-period

Than calculate the estimated total accruals

$$
\frac{T A C C i t}{T A i, t-1}=\alpha 1\left(\frac{1}{T A i, t-1}\right)+\alpha 2\left(\frac{\Delta R E V i t-\Delta R E C i t}{T A i, t-1}\right)+\alpha 3\left(\frac{\text { PPEit }}{T A i, t-1}\right)
$$

Information:

TACCit : total company accrual $\mathrm{i}$ in the $\mathrm{t}$-period

TAi, $\mathrm{t}-1 \quad$ : total assets of company $\mathrm{i}$ in the $\mathrm{t}$-period

$\alpha 1, \alpha 2, \alpha 3 \quad$ : regression coefficients

$\triangle$ REVit : company income $\mathrm{i}$ in the $\mathrm{t}$-period

$\triangle$ RECit : company receivables $\mathrm{i}$ in the t-period

PPEi $t \quad$ : fixed assets before the accumulation of company $\mathrm{i}$ in the t-period

\section{Second Step}

Calculate the NDACC (non discretionary)

$$
N D A C C i t=\alpha 1\left(\frac{1}{T A i, t-1}\right)+\alpha 2\left(\frac{\Delta R E V i t-\Delta R E C i t}{T A i, t-1}\right)+\alpha 3\left(\frac{\text { PPEi } t}{T A i, t-1}\right)
$$

Information:

NDACCit : non-discretionary accrual of company $i$ in the $t$-period

TAi, $t-1 \quad$ : total assets of company $\mathrm{i}$ in the $\mathrm{t}$-period

$\alpha 1, \alpha 2, \alpha 3 \quad$ : regression coefficients 
$\triangle$ REVit $\quad$ : company income $\mathrm{i}$ in the $\mathrm{t}$-period

$\triangle$ RECit : company receivables $i$ in the t-period

PPEi $\mathrm{t} \quad$ : fixed assets before the accumulation of company $\mathrm{i}$ in the $\mathrm{t}$-period

\section{Third Step}

Calculate the discretionary accruals (DA)

$$
\text { DACCit }=\frac{T A C C i t}{T A i, t-1}-N D A C C i t
$$

Information:

DACCit : discretionary accrual of company $\mathrm{i}$ in the $\mathrm{t}$-period

TACCit : total company accrual $\mathrm{i}$ in the $\mathrm{t}$-period

TAi, $t-1 \quad:$ total assets of company $i$ in the $t$-period

NDACCit : non-discretionary accrual of company $i$ in the t-period

\section{Independent Variables}

Bid Ask Spread. Bid ask spread is the distance between the highest price the buyer willing to pay and the lowest price the seller can accept. Bid ask spread is obtained from the result of the division between the ask price minus the bid first with the ask price plus the bid price. Can be calculated by the following formula

$$
\text { SPREADi, } t=\frac{(\text { aski, } t-b i d i, t)}{\{(\text { aski, } t+\text { bidi }, t) / 2\}} \times 100
$$

Information:

SPREADi, $\mathrm{t}$ : the distance between the price requested and received

Aski, $\mathrm{t} \quad$ : the highest price requested

Bidi, $\mathrm{t} \quad$ : the lowest price received

Profitability. Profitability is a ratio that illustrates the company's ability to generate profits in a certain time period. In this study using return on assets which describes the company's ability to generate profits using the assets of the company.

$$
\text { Return On Asset }=\frac{\text { Earning After Tax }}{\text { Total Equity }} \times 100
$$

Keterangan:

Return On Asset : asset return ratio

Earning After Tax : earning after tax

Total Equity : total equity

Free Cash Flow. Free cash flow is the remaining cash owned by the company after completing all investment activities and capital, where this cash will be given to shareholders as dividends. Free cash flow can be calculated by dividing cash flow from operational activities reduced by cash flow from investing activities in advance with the total assets of a company. Can be calculated by the following formula 


$$
\text { Free Cash Flow }=\frac{\text { operating Cash Flow-Investing Cash Flow }}{\text { Total Asset }}
$$

Information:

Free Cash Flow : free cash flow

Operating Cash Flow : operational cash flow

Investing Cash Flow : investment cash flow

Total Assets

: total assets

The hypothesis that has been formulated will be tested by various methods, namely $\mathrm{t}$ test, $\mathrm{F}$ test, and the coefficient of determination test $\left(\mathrm{R}^{2}\right)$. The relationship between bid ask spread, profitability, and free cash flow with earnings management can be seen using the multiple regression analysis method with the regression model stated as follows

$\begin{array}{ll}\mathrm{EM}=\alpha+\beta_{1} \text { BIDASKSPREAD }+\beta_{2} \mathrm{PR} \\ \text { Information: } \\ \mathrm{Y} & : \text { Earning Management } \\ \alpha & : \text { Constants } \\ \beta 1 \beta 2 \beta 3 \beta 4 & : \text { Regression coefficient } \\ \mathrm{X} 1 & \text { : Bid Ask Spread } \\ \mathrm{X} 2 & \text { : Profitability } \\ \mathrm{X} 3 & \text { : Free Cash Flow } \\ \mathrm{e} & \text { : Error }\end{array}$

Data processing using Microsoft Excel programs and model selection, descriptive statistical tests, and hypothesis testing using the E-views 10+ program.

\section{THE RESULTS OF STATISTICAL TESTS}

This study uses a purposive sampling technique in which the total sample of companies is 69 companies with a total data of 207 data. The following is a sample selection using purposive sampling. 
Table 1. Sample Criteria

\begin{tabular}{c|l|c}
\hline No & \multicolumn{1}{|c|}{ Sample Criteria } & Total \\
\hline 1 & \multicolumn{1}{|c}{\begin{tabular}{c}
\multicolumn{1}{|c}{} \\
Manufacturing companies listed on the Indonesia Stock Exchange in 2015-2018
\end{tabular}} & 156 \\
\hline 2 & $\begin{array}{l}\text { Manufacturing companies listed on the Indonesia Stock Exchange that do not } \\
\text { publish consecutive financial reports for 2015-2018 }\end{array}$ & $(16)$ \\
\hline 3 & $\begin{array}{l}\text { Manufacturing companies listed on the Indonesia Stock Exchange that do not } \\
\text { receive profits in a row in 2015-2018 }\end{array}$ & $(41)$ \\
\hline 4 & $\begin{array}{l}\text { Manufacturing companies listed on the Indonesia Stock Exchange whose financial } \\
\text { statements are not presented in Rupiah }\end{array}$ & $(28)$ \\
\hline \multicolumn{2}{l}{ Data outlier } & $(2)$ \\
\hline \multicolumn{2}{l}{ Number of manufacturing company samples during the research year } & 69 \\
\hline \multicolumn{2}{l}{ Number of manufacturing company data during the research year } & 207 \\
\hline
\end{tabular}

Source: (Data Prossed, 2018)

Descriptive Statistics. Descriptive statistical analysis illustrates the mean (mean), median (median), minimum value, maximum value, and standard deviation. The following are the results of the descriptive statistical analysis:

Table 2. Descriptive Statistics

\begin{tabular}{lllll}
\hline & EM & SPREAD & ROA & FCF \\
\hline Mean & 0.134738 & 7.868970 & 0.085367 & $1.32 \mathrm{E}+12$ \\
Median & 0.123769 & 1.156069 & 0.057963 & $1.47+11$ \\
Maximum & 1.235023 & 200 & 0.920997 & $2.77 \mathrm{E}+13$ \\
Minimum & -0.061427 & -200 & 0.000282 & $-3.03 \mathrm{E}+12$ \\
Std. Dev. & 0.121930 & 4.882263 & 0.102725 & $3.77 \mathrm{E}+12$ \\
\hline
\end{tabular}

Source: (Data Prossed, 2018)

On the dependent variable, earnings management has a minimum value of -0.061427 owned by SRSN or Indo Acidatama Tbk in 2016, while earnings management has a maximum value of 1.235023 owned by MERK or Merck Tbk companies in 2018. The average value of the variable earnings management is 0.134738 and the standard deviation of earnings management is 0.121930 .

The bid-ask spread variable has a maximum value of 200 owned by 2016 LION or Lion Metal Works Tbk companies, SRSN or Indo Acidatama Tbk in 2016 and 2017, TALF or Tunas Alfin Tbk in 2016, ALDO or Alkindo Naratama Tbk in 2017, KDSI or Kedawung Setia Industrial Tbk in 2016, JECC or Jembo Cable Company Tbk in 2018, KBLI or KMI 
Wire \& Cable Tbk in 2016 and VOKS or Voksel Electric Tbk in 2016. The minimum value of the bid-ask spread $\neg$ as large as -200 is owned by ALDO or Alkindo Naratama Tbk in 2016. The average value of the bid-ask spread variable is 7.868970 and the standard deviation value is 48.82263 .

The profitability variable has a maximum value of 0.920997 owned by MERK or Merck Tbk companies in 2018, while the minimum value of 0.000282 owned by STAR or Star Petrochem Tbk companies in 2018. The average value owned by the profitability variable is 0.085367 with a standard deviation of 0.102725 .

The free cash flow variable has a maximum value of $2.77 \mathrm{E}+13$ owned by the ASII company or Astra International Tbk in 2018, while the minimum value of $-3.03 \mathrm{E}+12$ owned by the WSBP company or Waskita Beton Precast Tbk in 2016. The average value which has a free cash flow variable of $1.32 \mathrm{E}+12$ with a standard deviation of $3.77 \mathrm{E}+12$.

Panel Model Estimation Test Results. The panel data model that can be used in this study through E-views 10+ software to determine which panel data model is appropriate and appropriate is the Common Effect Model, Fixed Effect Model, and Random Effect Model.

Common Effect Model. It is the simplest panel data model because the common effect model is a combination of cross section data with time series data. The following are the results of the Common Effect Model in this study:

Table 3. Common Effect Model

\begin{tabular}{|c|c|c|c|c|}
\hline \multicolumn{5}{|c|}{$\begin{array}{l}\text { Dependent Variable: } Y \\
\text { Method: Panel Least Squares } \\
\text { Date: } 12 / 18 / 19 \text { Time: } 21: 07 \\
\text { Sample: } 20162018 \\
\text { Periods included: } 3 \\
\text { Cross-sections included: } 69 \\
\text { Total panel (balanced) observations: } 207\end{array}$} \\
\hline Variable & Coefficient & Std. Error & t-Statistic & Prob. \\
\hline $\mathrm{C}$ & 0.092334 & 0.009696 & 9.522802 & 0.0000 \\
\hline $\mathrm{X} 1$ & $-3.75 E-05$ & 0.000150 & -0.249967 & 0.8029 \\
\hline X2 & 0.619664 & 0.073239 & 8.460794 & 0.0000 \\
\hline X3 & $-7.75 E-15$ & $2.00 \mathrm{E}-15$ & -3.885351 & 0.0001 \\
\hline R-squared & 0.272143 & \multicolumn{2}{|c|}{ Mean dependent var } & 0.134738 \\
\hline Adjusted R-squared & 0.261387 & \multicolumn{2}{|c|}{ S.D. dependent var } & 0.121930 \\
\hline S.E. of regression & 0.104790 & \multicolumn{2}{|c|}{ Akaike info criterion } & -1.654588 \\
\hline Sum squared resid & 2.229119 & \multicolumn{2}{|c|}{ Schwarz criterion } & -1.590188 \\
\hline Log likelihood & 175.2499 & \multicolumn{2}{|c|}{ Hannan-Quinn criter. } & -1.628545 \\
\hline F-statistic & 25.30037 & \multicolumn{2}{|c|}{ Durbin-Wats on stat } & 1.295262 \\
\hline Prob(F-statistic) & 0.000000 & & & \\
\hline
\end{tabular}

Source: (Data Prossed, 2018)

Fixed Effect Model. This model estimates that between time series data and cross section data there are individual differences so that a dummy variable is included to estimate this 
model to see differences in intercepts that exist between companies. The following are the results of the Fixed Effect Model:

Table 4. Fixed Effect Model

\begin{tabular}{|c|c|c|c|c|}
\hline \multicolumn{5}{|c|}{$\begin{array}{l}\text { Dependent Variable: } Y \\
\text { Method: Panel Least Squares } \\
\text { Date: } 12 / 18 / 19 \text { Time: } 21: 10 \\
\text { Sample: } 20162018 \\
\text { Periods included: } 3 \\
\text { Cross-sections included: } 69 \\
\text { Total panel (balanced) observations: } 207\end{array}$} \\
\hline Variable & Coefficient & Std. Error & t-Statistic & Prob. \\
\hline $\mathrm{C}$ & 0.080497 & 0.015576 & 5.167890 & 0.0000 \\
\hline$\times 1$ & 5.38E-06 & 0.000137 & 0.039324 & 0.9687 \\
\hline$\times 2$ & 1.265289 & 0.123085 & 10.27977 & 0.0000 \\
\hline$\times 3$ & $-4.09 E-14$ & $8.20 E-15$ & -4.990373 & 0.0000 \\
\hline \multicolumn{5}{|c|}{ Effects Specification } \\
\hline \multicolumn{5}{|c|}{ Cross-section fixed (dummy variables) } \\
\hline R-squared & 0.713360 & \multirow{7}{*}{\multicolumn{2}{|c|}{$\begin{array}{l}\text { Mean dependent var } \\
\text { S.D. dependent var } \\
\text { Akaike info criterion } \\
\text { Schwarz criterion } \\
\text { Hannan-Quinn criter. } \\
\text { Durbin-Watson stat }\end{array}$}} & 0.134738 \\
\hline Adjusted R-squared & 0.562609 & & & 0.121930 \\
\hline S.E. of regression & 0.080639 & & & -1.929460 \\
\hline Sum squared resid & 0.877858 & & & -0.770254 \\
\hline Log likelihood & 271.6991 & & & -1.460687 \\
\hline F-statistic & 4.732030 & & & 2.528768 \\
\hline Prob(F-statistic) & 0.000000 & & & \\
\hline
\end{tabular}

Source: (Data Prossed, 2018)

Chow Test. The Chow test was carried out with the aim of finding the most appropriate and appropriate panel data regression between the Common Effect Model or Fixed Effect Model with a significance level of 0.05 or $5 \%$. The hypothesis formulation is Ho which is the Common Effect Model while Ha is the Fixed Effect Model. The conclusion reached in the Chow test is made with the following conditions: (a) if the probability value in the crosssection $\mathrm{F}<0.05$, then Ho is rejected. (b) if the probability value in the cross-section $\mathrm{F}>0.05$, then Ho is accepted. (c) If Ho is rejected, the next research to be carried out is the Hausman test to determine the most appropriate and appropriate panel data regression between the Fixed Effect Model or the Random Effect Model. The following are the Chow test results:

Table 5. Chow Test

\begin{tabular}{|c|c|c|c|}
\hline \multicolumn{4}{|c|}{ Redundant Fixed Effects Tests } \\
\hline \multicolumn{4}{|l|}{ Equation: $\mathrm{CHOW}$} \\
\hline \multicolumn{4}{|c|}{ Test cross-section fixed effects } \\
\hline Effects Test & Statistic & d.f. & Prob. \\
\hline Cross-section F & 3.055906 & $(68,135)$ & 0.0000 \\
\hline Cross-section Chi-square & 192.898554 & 68 & 0.0000 \\
\hline
\end{tabular}

Source: (Data Prossed, 2018) 
Based on Table 5, the probability of the cross-section $\mathrm{F}$ is equal to 0.0000 which is smaller than $0.05(0.0000<0.05)$ so that in this study the right and appropriate model is the fixed effect model. Then proceed with the Hausman test to determine the right model and in accordance between the Fixed Effect Model or Random Effect Model.

Random Effect Model. Even if there are interference variables, this model will still estimate the panel data that should be. Here are the results of the Random Effect Model:

Table 6. Random Effect Model

\begin{tabular}{|c|c|c|c|c|}
\hline \multicolumn{5}{|c|}{$\begin{array}{l}\text { Dependent Variable: } Y \\
\text { Method: Panel EGLS (Cross-section random effects) } \\
\text { Date: } 12 / 18 / 19 \text { Time: } 21: 13 \\
\text { Sample: } 20162018 \\
\text { Periods included: } 3 \\
\text { Cross-sections included: } 69 \\
\text { Total panel (balanced) observations: } 207 \\
\text { Swamy and Arora estimator of component variances }\end{array}$} \\
\hline Variable & Coefficient & Std. Error & t-Statistic & Prob. \\
\hline $\mathrm{C}$ & 0.082216 & 0.011084 & 7.417524 & 0.0000 \\
\hline $\mathrm{X} 1$ & $-1.14 \mathrm{E}-05$ & 0.000127 & -0.090059 & 0.9283 \\
\hline $\mathrm{X} 2$ & 0.771290 & 0.077134 & 9.999301 & 0.0000 \\
\hline X3 & $-1.01 E-14$ & $2.33 \mathrm{E}-15$ & -4.318471 & 0.0000 \\
\hline \multicolumn{5}{|c|}{ Weighted Statistics } \\
\hline R-squared & 0.305155 & \multirow{5}{*}{\multicolumn{2}{|c|}{$\begin{array}{l}\text { Mean dependent var } \\
\text { S.D. dependent var } \\
\text { Sum squared resid } \\
\text { Durbin-Watson stat }\end{array}$}} & 0.086240 \\
\hline Adjusted R-squared & 0.294887 & & & 0.104421 \\
\hline S.E. of regression & 0.087683 & & & 1.560737 \\
\hline F-statistic & 29.71722 & & & 1.712194 \\
\hline Prob(F-statistic) & 0.000000 & & & \\
\hline \multicolumn{5}{|c|}{ Unweighted Statistics } \\
\hline R-squared & 0.255007 & \multirow{2}{*}{\multicolumn{2}{|c|}{$\begin{array}{l}\text { Mean dependent var } \\
\text { Durbin-Watson stat }\end{array}$}} & 0.134738 \\
\hline Sum squared resid & 2.281600 & & & 1.171233 \\
\hline
\end{tabular}

Source: (Data Prossed, 2018)

Hausman Test. The Hausman test was carried out with the aim of finding the most appropriate and appropriate panel data regression between the Fixed Effect Model or Random Effect Model with a significance level of 0.05 or 5\%. The hypothesis formulation is Ho which is the Random Effect Model while Ha is the Fixed Effect Model. The conclusions reached in the Hausman test were made with the following conditions: (a) if the probability value in a random cross-section $<0.05$, then Ho is rejected. (b) if the probability of a random cross-section> 0.05 , then Ho is accepted. The following are the results of the Hausman test: 
Table 7. Hausman Tes

\begin{tabular}{|c|c|c|c|}
\hline \multicolumn{4}{|c|}{ Correlated Random Effects - Hausman Test } \\
\hline \multicolumn{4}{|l|}{ Equation: HAUSMAN } \\
\hline \multicolumn{4}{|c|}{ Test cross-section random effects } \\
\hline Test Summary & $\begin{array}{l}\text { Chi-Sq. } \\
\text { Statistic }\end{array}$ & Chi-Sq. d.f. & Prob. \\
\hline Cross-section random & 40.015540 & 3 & 0.0000 \\
\hline
\end{tabular}

Source: (Data Prossed, 2018)

Based on Table 7, the random cross-section probability is 0.0000 which is smaller than $0.05(0.0000<0.05)$ so that from the results of the Hausman test the best model in this study is the fixed effect model.

Multiple Linear Regression Analysis Test Results. After a descriptive statistical test and panel data estimation, a multiple linear regression analysis test with a significance of 5\% is needed to determine the amount of influence of the independent variables on the dependent variable. In this study, multiple linear regression analysis was performed to determine the effect of bid-ask spread (X1), profitability (X2) and free cash flow (X3) on earnings management in manufacturing companies listed on the Stock Exchange in 2016-2018. The data model used is the Fixed Effect Model which is determined based on the results of the data assumptions using the Chow test and the Hausman Test. The results of the multiple linear regression analysis are presented as follows:

Table 8. Multiple Linear Regression Analysis

\begin{tabular}{l|c|c|c|c}
\hline Variable & Coefficient & Std. Error & t-Statistic & Prob. \\
\hline $\mathrm{C}$ & $\mathbf{0 . 0 8 0 4 9 7}$ & 0.015576 & 5.167890 & 0.0000 \\
\hline $\mathrm{X} 1$ & $\mathbf{5 . 3 8 E - 0 6}$ & 0.000137 & 0.039324 & 0.9687 \\
\hline $\mathrm{X} 2$ & $\mathbf{1 . 2 6 5 2 8 9}$ & 0.123085 & 10.27977 & 0.0000 \\
\hline $\mathrm{X} 3$ & $\mathbf{- 4 . 0 9 E - 1 4}$ & $8.20 \mathrm{E}-15$ & -4.990373 & 0.0000 \\
\hline
\end{tabular}

Source: (Data Prossed, 2018)

Based on table 5, the equation of the research model is as follows:

$$
\begin{aligned}
& \mathrm{Y}=0.080497+5.38 \mathrm{E}-06 \mathrm{X} 1+1.265289 \mathrm{X} 2-4.09 \mathrm{E}-14 \mathrm{X} 3+\varepsilon . \\
& \text { Information: } \\
& \mathrm{Y} \quad \text { : Earnings Management } \\
& \mathrm{C} \quad \text { : Constanta } \\
& \mathrm{X} 1 \quad: \text { Bid-ask Spread } \\
& \mathrm{X} 2 \quad: \text { Profitability } \\
& \mathrm{X} 3 \quad: \text { Free Cash Flow } \\
& \mathrm{e} \quad \text { : Error }
\end{aligned}
$$


Based on the multiple linear regression equation, it can be explained that the constant value of 0.080497 means the value of the earnings management variable is 0.080497 , if the value of the bid-ask spread variable, profitability, and free cash flow is zero.

The multiple regression coefficient value of the bid-ask spread variable is 5.38E-06 where if the value of $\mathrm{X} 1$ has increased by one unit then earnings management will increase by $5.38 \mathrm{E}-06$ assuming that the variables $\mathrm{X} 2$ and $\mathrm{X} 3$ are constant, and vice versa.

The multiple regression coefficient value of profitability variable is 1.265289 where if the value of X2 has increased by one unit, earnings management will increase by 1.265289 assuming that the variables $\mathrm{X} 1$ and $\mathrm{X} 3$ are constant, and vice versa.

The multiple regression coefficient value of the free cash flow variable is $-4.09 \mathrm{E}-14$ where if the $\mathrm{X} 3$ value increases by one unit then earnings management will decrease by 4.09E-14 assuming that the variables $\mathrm{X} 1$ and $\mathrm{X} 2$ are constant, and vice versa.

Test Results F. After conducting multiple regression analysis tests, simultaneous tests or F tests are performed with a significance of $5 \%$ with the aim of determining the effect of variable bid-ask spread (X1), profitability (X2), and free cash flow (X3) on earnings management together or simultaneous. The conclusions of the $\mathrm{F}$ test were carried out according to the following conditions: (a) If the F-statistic probability $<0.05$ then the regression model used in this study was appropriate and appropriate. (b) If the F-statistic probability> 0.05 then the regression model used in this study is inaccurate and inappropriate. The following $\mathrm{F}$ test results are presented:

Table 9. F Test

\begin{tabular}{ll}
\hline F-statistic & 4.732030 \\
\hline Prob(F-statistic) & $\mathbf{0 . 0 0 0 0 0 0}$ \\
\hline
\end{tabular}

Based on the F test results in Table 9, it can be concluded that the bid-ask spread variable (X1), profitability (X2), and free cash flow (X3) have a simultaneous effect on earnings management (Y). This is because the F-Statistic probability value of 0.000000 is smaller than 0.05 , therefore the panel data regression model is appropriate and suitable for use in this study.

Test Results t. After carrying out simultaneous tests or F tests to determine whether the regression model is appropriate and appropriate for use, a partial test or t test with a significance of $5 \%$ is used to determine the effect of each independent variable bid-ask spread (X1), profitability (X2), and free cash flow (X3) to earnings management. The conclusions drawn from conducting the t test are with the condition: (a) If the probability of the independent variable is $<0.05$ then the independent variable tested has a significant effect on the dependent variable. (b) If the probability of the independent variable is $>0.05$ then the independent variable tested does not have a significant effect on the dependent variable. The following are the results of the $t$ test: 
Table 10. $t$ Test

\begin{tabular}{l|l|l|l|l}
\hline Variable & Coefficient & Std. Error & t-Statistic & Prob. \\
\hline $\mathrm{C}$ & 0.080497 & 0.015576 & 5.167890 & 0.0000 \\
\hline $\mathrm{X} 1$ & $5.38 \mathrm{E}-06$ & 0.000137 & 0.039324 & 0.9687 \\
\hline $\mathrm{X} 2$ & 1.265289 & 0.123085 & 10.27977 & 0.0000 \\
\hline $\mathrm{X} 3$ & $-4.09 \mathrm{E}-14$ & $8.20 \mathrm{E}-15$ & -4.990373 & 0.0000 \\
\hline
\end{tabular}

Source: (Data Prossed, 2018)

Based on the results of the $t$ test in table 10, the probability value of the bid-ask spread variable is 0.9687 , which means the probability value is greater than the significance value of 0.05 , so it can be concluded that the bid-ask spread has a positive and not significant effect on earnings management.

The profitability variable probability value of 0.0000 which means the probability value is smaller than the significance value of 0.05 , so it can be concluded that profitability has a positive and significant effect on earnings management.

The free cash flow variable probability value is 0.0000 , which means the probability value is smaller than the significance value of 0.05 , so it can be concluded that free cash flow has a negative and significant effect on earnings management.

Determination Coefficient Test Results (R2). Determination coefficient test conducted with a significance of $5 \%$ aims to determine how much the ability of the independent variable bid-ask spread (X1), profitability (X2), and free cash flow (X3) can explain the dependent variable earnings management.

Table 11. Determinant Coefficient Test

\begin{tabular}{l|l}
\hline $\boldsymbol{R}$-squared & 0.713360 \\
\hline Adjusted R-squared & 0.562609 \\
\hline
\end{tabular}

Based on the determinant coefficient test in Table 11, it can be concluded that the variable bid-ask spread, profitability, and free cash flow can explain earnings management variables of 0.562609 or $56.3 \%$, the rest of 0.437391 or $43.7 \%$ of earnings management variables can be explained by other factors outside this research variable.

\section{DISCUSSION}

The purpose of this study is to determine the effect of bid-ask spread, profitability, and free cash flow on earnings management. The subjects of this study were all manufacturing companies listed on the Indonesia Stock Exchange in 2016-2018.

Effect of Bid-ask Spreads on Earnings Management. The first hypothesis is the bid-ask spread has a positive and significant effect rejected because according to the results of data analysis as shown in table 10 the bid-ask spread has a probability value of 0.9687 where the value is greater than the significance level of 0.05 which means it is not significant. However, the bid-ask spread coefficient value of 5.38E-06 shows the bid-ask spread has a 
positive effect on earnings management so the results of this study indicate that the bid-ask spread has a positive and not significant effect on earnings management. It can be concluded that when the bid-ask spread has increased, earnings management has also increased and when the bid-ask spread has decreased, earnings management has decreased.

This study is in line with the results of previous studies of (Putri and Sujana, 2018), and (Hanifah, 2015) where the bid-ask spread does not significantly influence earnings management. However, it is inversely proportional to the results of research conducted by (Putu et al., 2015) where bid-ask spread has a positive and significant effect on earnings management.

The result of this research is not consistent with agency theory which states that information asymmetry can influence managers to do earnings management because of differences in information held by management as agents and investors as principals, because in this study it is explained that differences in information held by agents and principals do not encourage managers in do earnings management in the company. The impact resulting from the information asymmetry can occur due to an unplanned reporting of financial statements and is not the result of an intention to conduct earnings management.

Effect of Profitability on Earnings Management. The second hypothesis that profitability has a positive and significant effect is accepted because according to the results of data analysis as in table 10 the resulting profitability has a probability value of 0.0000 where the value is smaller than the significance level of 0.05 which means it has a significant effect. However, the profitability coefficient value of 1.265289 shows profitability has a positive effect on earnings management so the results of this study indicate that profitability has a positive and significant effect on earnings management. It can be concluded that when profitability increases, earnings management also increases, and when profitability decreases, earnings management also decreases.

This study is in line with the results of the study of (Fitri et al., 2018) and (Alexander and Hengky, 2017) that profitability has a positive and significant effect on earnings management. However, it is inversely proportional to the results of research conducted by (Wiyadi et al., 2015) and (Agustia and Suryani, 2018) that profitability has no significant effect on earnings management.

The results of this study are in line with agency theory where when there is a big change in the profitability of the company, there is a large fluctuation in profitability in the ability of management to generate profits. This can influence investors in predicting income and assessing risk in investment so that it impacts on investor confidence in the company, so management is encouraged to manage earnings so that reported earnings do not fluctuate and this will increase investor confidence so as to make investors to continue investing in the company. The higher ROA results as a percentage of a company's profit, the more assets are used to generate profits. ROA aims to assess whether a company is good or not, because it can affect investors because of high returns. So it can be concluded that the higher the percentage of ROA results, the higher the productivity of assets in generating profits. Then ROA strongly encourages management to practice earnings management.

Effect of Free Cash Flow on Earnings Management. The third hypothesis that free cash flow has a positive and significant effect is rejected because according to the results of data analysis as shown in table 10 the free cash flow has a probability value of 0.0000 where the 
value is smaller than the 0.05 significance level which means it has a significant effect. However, the free cash flow coefficient value of $-4.09 \mathrm{E}-14$ shows that free cash flow has a negative effect on earnings management so the results of this study indicate that free cash flow has a negative and significant effect on earnings management. It can be concluded that when free cash flow increases, earnings management will decrease and when free cash flow decreases, earnings management will increase.

This study is in line with the results of previous studies namely (Hastuti et al., 2018) where free cash flow has a positive and significant effect on earnings management but the results of this study are inversely proportional to the research results of (Rahmadhani et al., 2017) that free cash flow has no effect on earnings management because according to him the size of cash flow has no effect on earnings management practices.

High free cash flow encourages managers to conduct earnings management because more cash is obtained after funding the company's obligations such as paying debts, paying dividends, and others that have been done, used by management to carry out projects that are profitable for themselves and not profitable for company. This requires good internal control within the company so that it can reduce earnings management practices that can harm the company.

\section{CONCLUSION}

The purpose of this study was to determine the effect of bid ask spread, profitability, and free cash flow on earnings management. The population in this study are manufacturing companies listed on the Indonesia Stock Exchange in 2016-2018. The sampling method used was purposive sampling with predetermined criteria. Earning management is determined by the accruals method. The results of this study stated that the bid ask spread did not have a significant effect on earnings management, while profitability and free cash flow had a significant effect on earnings management.

The research model used in this study is to use multiple linear regression analysis and use the fixed effects model panel data. The program used in this study to test data and hypotheses is to use the E-views 10+ software. Based on the results of t-test statistics or partial tests conducted in this study, it can be concluded that it shows that the bid-ask spread has a significance value greater than the predetermined significance value, so that the independent variable bid-ask spread has no significant effect on earnings management. Profitability has a significance value smaller than the predetermined significance value and the coefficient value is positive, so the independent variable profitability has a positive and significant effect on earnings management. Free cash flow has a significance value less than the predetermined significance value and the coefficient value is negative, so the independent variable free cash flow has a negative and significant effect on earnings management in manufacturing companies listed on the Indonesia Stock Exchange in 20162018.

Based on the results of the $\mathrm{F}$ test or the simultaneous test conducted in this study, it can be concluded that the independent variable bid-ask spread, profitability, and free cash flow together or simultaneously have an influence on the dependent variable of earnings management. Based on the results of testing the coefficient of determination (R2) that has been done in this study, it can be concluded that the relationship between the independent variables to the dependent variable is less strong because it is only 0.562609 or $56.3 \%$ 
earnings management dependent variables that can be explained by the independent variables used in this study, while 0.437391 or $43.7 \%$ dependent variable earnings management is explained by other independent variables not used in this study.

This research is not far from limitations, namely: (1) The period carried out in this study is too short, because it only uses a period of 3 years, namely 2016-2018. (2) The sample data population used in this study is limited because it only uses manufacturing companies listed on the Indonesia Stock Exchange and the number of sample data is only 207 samples from 156 manufacturing companies because of the limitations of manufacturing companies in meeting the criteria set by researchers to be the sample in this study. (3) This study only uses three independent variables, namely bid-ask spread, profitability, and free cash flow and other independent variables that can strengthen the influence of earnings management are not used in this study. (4) Proxies used to calculate earnings management only use discretionary accruals with a modified Jones model.

Based on the limitations outlined above, there are a number of suggestions that can be useful for further research, namely: (1) Extend the research period so that it can obtain different results from the results of this study and get more accurate results. (2) Further research can expand the research sector not only to manufacturing companies, for example can use banking companies. (3) Future studies can use independent variables that can affect earnings management that are not used in this study, such as company size, company value, and others. (4) Future studies can measure the dependent variable of earnings management by using other proxies such as the Healy model, the Dechow-Dichev model, and the Jones model.

\section{REFERENCES}

Agustia, Yofi P. and Suryani, Elly.(2018). Pengaruh Ukuran Perusahaan, Umur Perusahaan, Leverage, Dan Profitabilitas Terhadap Manajemen Laba (Studi Pada Perusahaan Pertambangan yang Terdaftar di Bursa Efek Indonesia Periode 2014-2016). Jurnal ASET, 10(1), 63-74.

Alexander, N., and Hengky. (2017). Factors Affecting Earnings Management in the Indonesian Stock Exchange. J. Bank. Fin. Review, 2(2), 8-14.

Ali, Ahmadi, and Abdelfettah Bouri. (2016). "International Academic Journal of Accounting and Financial Management An Essay to Analyze Information Asymmetry: Originality and Ways to Reducing the Level of Information Asymmetry." International Academic Journal of Accounting and Financial Management, vol. 3, no. 3, 2016, pp. 32-39, www.iaiest.com.

Bukit, R., and Nasution, N.F. (2015). Employee Diff, Free Cash Flow, Corporate Governance and Earning Management. Preocedia Social and Behavioral Scrences, 211, 585-594.

Cardoso, C. T. F., Martinez, L, A., and Teixeira. C. J. A. (2014). Free Cash Flow and Earnings Management in Brazil: The Negative Side of Financial Slack. Global Jurnal of Management and Business Study Accounting and Auditing, 14(1), 84-96.

Chinthya, N. C., and Indriani, M. (2015). Arus Kas, Komite Audit dan Manajemen Laba Studi pada Perusahaan Manufaktur Indonesia. Jurnal Dinamika Akuntansi dan Bisnis, 2(2), 167-183.

Dewi, Adistie Nucke Arista, and Kartika Indri. (2016). "Faktor-Faktor Yang Mempengaruhi 
Bid-Ask Spread Pada Perusahaan Manufaktur.” Jurnal Akuntansi Indonesia, vol. 4, no. 2, 2016, p. 85, doi:10.30659/jai.4.2.85-96.

Fitri, A., Muda, I., and Badaruddin. (2018). The Influence of Good Corporate Governance, Leverage, and Profitability on Earning Management with Firm Size as Moderating Variable in the Banking Companies Listed In Indonesia Stock Exchange in the Period of 2012-2016. International Journal of Research and Review, 5(9),49-66.

Ghanbari, M., Manesh. M. Z., Khorasami, H., Hesam, M., and Nejad,H. (2016)."PAT (Positive Accounting Theory) and Natural Science." International Research Journal of Applied and Basic Sciences Science Explorer Publications, vol. 10, no. 2, 2016, pp. 177-82, www.irjabs.com.

Gunawan, I. K., Darmawan, N. A. S., and Purnamawati, I. G. A. (2015). Pengaruh Ukuran Perusahaan, Profitabilitas, dan Leverage terhadap Manajemen Laba pada Perusahaan Manufaktur yang Terdaftar di Bursa Efek Indonesia (BEI) [ The Influence of Company Size, Profitability, and Leverage on Earnings Management at Manufacturing Companies Listed on Indonesia Stock Exchange (IDX)]. JIMAT (Jurnal Ilmiah Mahasiswa Akuntansi S1), 3(1).

Hanifah. (2015). "The Influence Model of Good Corporate Governance and The Mechanism of Asymmetric Information in Minimizing The Practice of Earnings Management in Companies Included In The LQ 45 and Registered On IDX." International Journal of Business, Economics and Law, vol. 8, no. 1, 2015, pp. 9-17.

Hastuti, C. S. F., Arfan, M., \& Diantimala, Y. (2018). The Influence of Free Cash Flow and Operating Cash Flow on Earnings Management at Manufacturing Firms Listed in the Indonesian Stock Exchange. International Journal of Academic Research in Business \& Social Sciences, 8(9), 1133-1146.

Kasmir, (2014). Analisis Laporan Keuangan, Edisi Pertama, Cetakan Ketujuh. Jakarta: PT. Rajagrafindo Persada.

Mulyana, A., Zuraida., and Saputra, M. (2018). The Influence of Liquidity, Profitability and Leverage on Profit Management and Its Impact on Company Value in Manufacturing Company Listed on Indonesia Stock Exchange Year 2011-2015. International Journal of Managerial Studies and Research, 6(1), 8-14. https://doi.org/10.20431/2349-0349.0601002.

Nekhili, M., Amar, B. F. I., Chtioui, T., and Lakhal. F. C. (2016). Free Cash Flow and Earning Management: The Moderating Role of Governance and Ownership. The JournalofApplied Business Study, 32(1), 255-268.

Putri dan Sujana. (2018). "The Influence of Bid-Ask Spread and Leverage on Earnings Management with Good Corporate Governance as Moderating Variable." International Research Journal of Management, IT and Social Sciences, vol. 5, no. 3, 2018, pp. 8-21, doi:10.21744/irjmis.v5i3.663.

Putu, I. G., Andika,S., and Sukartha, I.M. (2015) Manajamen Laba. Fakultas Ekonomi Dan Bisnis Universitas Udayana ( Unud ), Bali , Indonesia Keagenan . Asimetri Informasi Muncul Ketika Manajer Lebih Mengetahui Informasi. 2015, pp. 1057-69.

Ramadhani, F., Latifah, S. W., and Wahyuni, E. D. (2017). Pengaruh Capital Intencity Ratio, Free Cash Flow, Kualitas Audit, dan Leverage terhadap Manajemen Laba pada Perusahaan Manufaktur yang Terdaftar Di BEI. Kompartemen: Jurnal Ilmiah Akuntansi, 15(2), 98-110. https://doi.org/10.30595/kompartemen.v15i2.1874.

Saftiana,Y.,Mukhtaruddin, Putri,K. W., and Ferina, I.S. (2018). "Corporate Governance 
Quality, Firm Size and Earnings Management: Empirical Study in Indonesia Stock Exchange.” Investment Management and Financial Innovations, vol. 14, no. 4, 2017, pp. 105-20, doi:10.21511/imfi.14(4).2017.10.

Wiyadi, Trisnawati, R., Sasongko, N., ad Fauzi, I.(2018). "The Effect Of Information Asymmetry, Firm Size, Leverage, Profitability And Employee Stock Ownership On Earnings Management With Accrual Model Wiyadi." International Journal of Business and Management and Law, vol. 8, no. 2, 2015, pp. 21-30.

Yogi, L., dan Damayanthi, I. (2016). Pengaruh Arus Kas Bebas, Capital Adequacy Ratio Dan Good Corporate Governance Pada Manajemen Laba. E-Jurnal Akuntansi, 15(2), 1056-1085. 